\title{
Janet Mann
}

\section{DO YOU HEAR ME?}

'Miко, have you seen the new student? He's cute!' Mei's eyes sparkled as she grabbed my arm.

'No, silly, I've just walked into the school. I've not even had a chance to put my things in my locker.'

'Well, I'm telling you, he's really cute. We have to find out about him before-oh!'

Mei's eyes were suddenly fixed over my shoulder. I turned, and found myself looking up into the palest blue eyes I had ever seen, framed by floppy blonde hair.

'Can you help me? I'm not sure where I should go, it's my first day here and I'm a little lost.' His voice was low and gentle, with a confidence which belied his words.

Before I could speak, Mei giggled and said, 'Stick with us, we'll look after you, eh Miko?'

'Well, that's a good start,' he smiled at me, 'now I know your name. I'm Michael—but everyone calls me Mike.'

'Ha! Mike and Miko,' spluttered Mei, smothering a snort of laughter—she'd seen the look on my face.

You read about it in magazines all the time, don't you-love at first sight.

I'd never believed it could happen. Until now.

I spent the next few days in a complete whirl. I couldn't concentrate on my lessons, I forgot my homework assignments, I spent hours doodling 'Mike and Miko' in my notebooks, drawing little hearts and arrows in glitter pen around our names. And yet, after that first meeting, I hardly saw him, we didn't share any lessons and there seemed to be no opportunities to "accidentally" bump into him. So I was really surprised to hear my name called as I left school on Friday afternoon. 
'Miko! Hey, Miko, wait up!' And there he was, a smile playing on his lips, one hand brushing his hair from his eyes, those blue, beautiful eyes.

'Can I walk you home?' He reached for my bag.

'Oh, I have to catch the MTR, I live in Mei Fu.'

'Then I'll catch the MTR with you — can't have you travelling alone. Pretty girls shouldn't travel alone.'

I was about to retort, 'I've been travelling alone on the MTR since I was seven-don't you know Hong Kong is the safest city?', when my brain registered what he'd said. Pretty. He'd called me pretty. So I smiled, and gave him my sports bag, and we walked towards the MTR.

And so it began. Each Friday he would wait after school, escort me to Mong Kok Station and see me to my apartment block. We'd stop at the 7-11 and buy drinks and lollies, and talk. Gradually we began to walk closer, hands touching, then arms linked. He had to put his arms round me to keep me steady as the train sped up and slowed down between stations.

The first time he kissed me it was so soft, so fleeting a moment I could hardly believe it had happened, but as the days and weeks passed his kisses became stronger, more insistent, even possessive-and I was as eager as he. So the night we arrived home to find my parents just rushing out with my younger brother to the hospital, after an accident in the communal playground, well, I guess it was inevitable. We were alone in the apartment. We were so in love, and so we made love. He was so confident, so sure of what he was doing, he showed me things about myself I never guessed existed. I didn't realise the importance of that till much later.

After that night things were different. He was different. He no longer asked if I would like to go to the cinema, or to the park; he decided where we would go and what we would do, but I was so in love I didn't care. Sometimes his parents would be away for business, and we could spend a few hours alone in their apartment, just being together.

That Friday, the day before the Spring Festival, I knew I had to tell him. I didn't know what to do, I couldn't even tell Mei. She would have been so shocked. We'd both been straight-A students with our eyes fixed on good grades, good careers. Now I'd thrown that all away; by being stupid, by falling in love. I had no one else to turn to but him.

His reaction was nothing like what I expected. Those beautiful, pale blue eyes turned cold and hard.

'I don't know what you expect me to do about it. You'll have to deal with it. 
Get rid of it. After all, how do I know it's mine?'

I cried and begged, clinging to him heartbroken, shocked at his sudden coldness. Eventually, he seemed to have a change of heart.

'Okay, Okay. We'd better get it over with. I'll come back with you and talk to your parents. It's not going to be easy ...' and he took my arm and led me towards the MTR Station.

That evening everywhere was so much busier than usual. Everyone rushing to and fro, their arms full of parcels and gifts for family and friends for the Spring Festival. A woman pushed past us carrying a mountain of bags overflowing with fruit; oranges spilling out of the top held only by their bright red net bags. Tall, spiky flowers held cradled in their arms were protected by other passengers wanting to get their traditional decorations home in one piece to set before the family altar. White lilies just opening gave off their heady, almost sickly scent as we slowly worked our way to the front of the platform queue. Train after train whooshed through the station, a flood of people pouring out onto the platform, pushing their way through, just as others pushed onto the train in their place. I was shoved and knocked, dimly aware that Mike was behind me, letting me be the one to meet the crowd, letting me take the knocks while he stood passive. The fruit, the lilies, the sweat, the noise, added to the heat building up became too much for me. I turned to Mike, grabbing his hand in both of mine.

'I-I think I'm going to faint,' I muttered.

'Be careful! Don't do that, everyone will guess what's happened if you faint. Keep focusing on my voice, the train's almost here.'

I felt the air pressure building up as the train approached through the tunnel, the rushing sound as it drew near the platform. I heard the announcement warning people to stand back and allow passengers to leave the train first as if it were coming from a long way away. I felt my eyes roll back, and my knees buckled. I felt, faint but insistent, a hand in the small of my back, a slight push ...

The safety doors were fitted at Mong Kok Station the very next day.

Some people say the sound of the safety doors as they open and close is like someone sighing. Some people say that as the soul leaves the body it sighs.

As you board your train at Mong Kok Station, do you hear me sigh? 